\title{
Sol-gel coatings for electrochromic devices
}

M. A. Macêdo, L. H. Dall'Antonia and M. A. Aegerter

Instituto de Física e Química de São Carlos Universidade de São Paulo

Caixa Postal 369, 13560 São Carlos, SP, Brazil

\section{$\underline{\text { ABSTRACT }}$}

Electrochromic devices have potential applications in architectural and automotive fields to regulate the transmission and reflection of the radiant energy. Preliminary characteristics of an all sol-gel window with the configuration glass $\backslash \mathrm{ITO} \backslash \mathrm{WO}_{3} \backslash \mathrm{TiO} \mathrm{T}_{2} \backslash \mathrm{TiO} \mathrm{O}_{2}-\mathrm{CeO}_{2} \backslash \mathrm{ITO} \backslash \mathrm{glass}$ is presented, and compared with another window where $\mathrm{WO}_{3}$ was deposited by evaporation. We also present preliminary data of a sol-gel $\mathrm{Nb}_{2} \mathrm{O}_{5}$ electrochromic layer as well as a thorough evaluation of the properties of a sol-gel $\mathrm{TiO}_{2}-\mathrm{CeO}_{2}$ ion storage coating where electrochemical properties are studied as a function of various parameters (thickness, heat treatment, etc.).

\section{INTRODUCTION}

The development of all solid state electrochromic devices such as smart windows and reflective mirrors is of utmost importance [1]. A typical system working in transmission is made of five layers sandwiched between two glass substrates (figure 1). There are two transparent electrical conductors (TC) which are required for setting up a distributed electric field, an electrochromic layer (EC), an ionic conductor (IC) and an ion storage layer (counter electrode) for $\mathrm{H}^{+}$or $\mathrm{Li}^{+}$ions (IS).

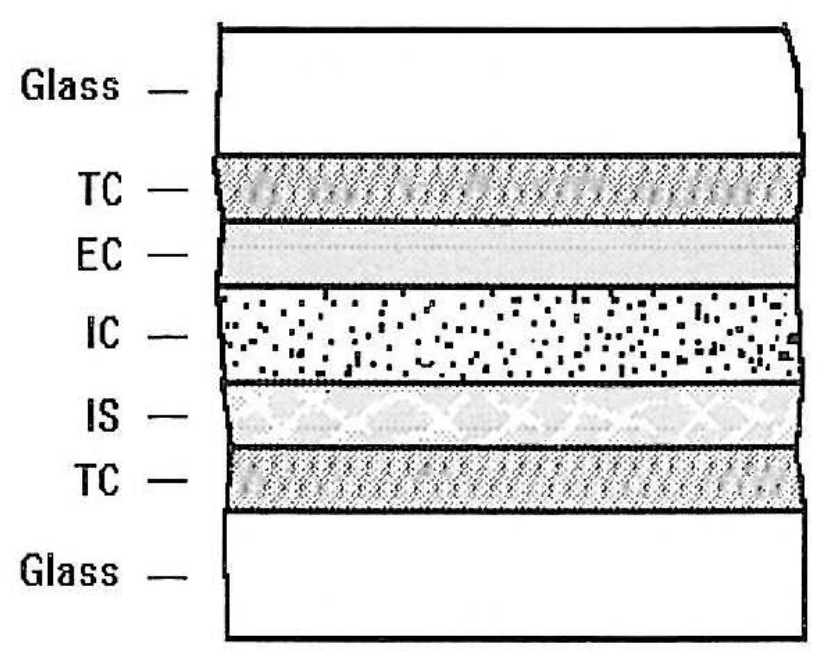

Figure 1. Schematic cross-section of a typical solid state electrochromic device working in transmission. TC=transparent electronic conductor, $\mathrm{EC}=$ electrochromic coating, IC=ionic conductor (electrolyte), IS=ion storage layer (counter electrode). 
When a small current is passed through the cell the ions stored in the counter electrode diffuse toward the electrochromic layer and change its transmittance continuously over a wide spectral range and consequently alter the overall optical transmission of the device. These devices have a time response which varies from seconds to less than a minute and most of them can maintain their optical properties when the power is turn off for several hours (memory effect). When the process is reversible, the original bleached state is obtained by reversing the applied voltage.

The current collecting layers are usually made of a mixed oxide $\mathrm{In}_{2} \mathrm{O}_{3}-\mathrm{SnO}_{2}$ (ITO) of low electrical resistivity.

Nowadays the preferred electrochromic layer is $\mathrm{wO}_{3}$ whose structure and color are modified by electrochemical insertion of ions following the reaction

$$
X A^{+}+x e^{-}+W O_{3}=A_{x} W O_{3}
$$

where $\mathrm{A}^{+}$can be $\mathrm{H}^{+}, \mathrm{Li}^{+}, \mathrm{Na}^{+}$, etc. The net result of the insertion reaction is the reduction of the transparent $\mathrm{wO}_{3}$ host material and its

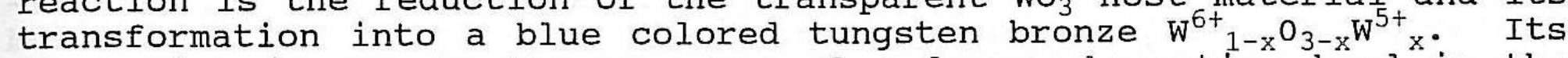
coloration is due to the presence of a large absorption band in the visible and near infrared region $\left(E_{\max } \approx 1.4 \mathrm{eV}\right)$ attributed to electronic transitions from the reduced tungsten ions states $\mathrm{W}^{5+}$ toward the conduction band $[2,3]$. Although the chemical diffusion of $\mathrm{Li}^{+}$ions is smaller than that of $\mathrm{H}^{+}$, these ions are preferred as hydrogen usually presents degassing phenomenon and the acid media of the electrolyte limits the lifetime of the devices [4].

Many electrolytes have been tested. The advantages of polymeric ion conductors over liquid ones is now recognized $[4,5]$ as they provide good electrolyte/electrode contact and present less problems of leakage. Among them polyethylene oxide (PEO) complexed with alkali salt such as $\mathrm{LiClO}_{4}$, $\mathrm{LiCF}_{3} \mathrm{SO}_{3}$ or $\mathrm{LiN}\left(\mathrm{SO}_{2} \mathrm{CF}_{3}\right)_{2}$ exhibits good $\mathrm{Li}^{+}$conductivity in the range $10^{-4}-10^{-7} \mathrm{~S} / \mathrm{cm}$ at room temperature.

Various oxides such as $\mathrm{V}_{2} \mathrm{O}_{5}[6,7], \operatorname{Ir}_{2} \mathrm{O}_{3}[8,9], \mathrm{CeO}_{2}[10]$ have been proposed for counter electrode but none of them exhibits ideal properties of transparency, reversibility and high kinetics for the electrochemical reaction with $\mathrm{Li}^{+}$ions. Recently we have proposed the use of $\mathrm{TiO}_{2}-\mathrm{CeO}_{2}$ layers prepared by sol-gel process; this compound allows a better Li+ insertion kinetics than pure $\mathrm{CeO}_{2}[7,11,12,13]$.

The sol-gel science [14] has now reached a point where it is possible to comtemplate the realization of a complete solid state electrochromic cell via such a process. In this paper we present up to date results relative to the preparation and caracterization of sol-gel electrochromic coatings of $\mathrm{WO}_{3}$ and $\mathrm{Nb}_{2} \mathrm{O}_{5}$ compositions, of a sol-gel protonic conductor based on $\mathrm{TiO}_{2}$ coating and an improved sol-gel preparation of the ion storage $\mathrm{TiO}_{2}-\mathrm{CeO}_{2}$ layer. The $\mathrm{Li}^{+}$charge density inserted or extracted in the ion storage layer is studied as a function of various parameters such as aging of sol, temperature and time of densification, thickness of the layer and type of ITO conductor. The optical response of a complete all solid state sol-gel window is presented and compared to a similar device built with coatings prepared by other methods of preparation. 


\subsection{Sol-gel coatings}

-The different layers of the complete sol-gel electrochromic cell have been obtained or prepared as following:

a) The transparent electric conductors (TC) were all ITO layers supplied by Balzers (Baltracon $\mathrm{Z20}, \rho=2.610^{-4} \Omega \mathrm{cm}$ ), Donally (FW 5005, $\rho=2.610^{-4}$ $\Omega \mathrm{cm}$ ) or Asahi Glass (plasma assisted evaporation $\rho=3.510^{-4} \Omega(\mathrm{cm})$.

b) Two different electrochromic coatings have beem developed. The first one is of $\mathrm{WO}_{3}$ composition and was prepared by sol-gel process using a colloidal solution $(0.5 \mathrm{M})$. This solution was acidified when it passed through an ion-exchange resin[15,16]. The colloidal solution was stabilized by addition of dimethyl sulfoxide $\left(\mathrm{CH}_{3}\right)_{2}$ so in order to avoid the precipitation of $\mathrm{WO}_{3} \cdot 2 \mathrm{H}_{2} \mathrm{O}$. The sol was sprayed on ITO coated glass substrates previously heated to a temperature of the order of $150 \mathrm{C}$. The second one is of $\mathrm{Nb}_{2} \mathrm{O}_{5}$ composition. Thin films were prepared by the solgel process arising by hydrolysis of niobium butoxide $\mathrm{Nb}\left(\mathrm{OBu}^{\mathrm{n}}\right)_{5}$ prepared via the sodium method[17]. Initially niobium chloride $\mathrm{NbCl}_{5}$ was dissolved in butanol; the solution was then mixed with sodium butoxide $\mathrm{Na}^{\left(O B \mathrm{O}^{\mathrm{n}} \text { ) }\right.}$ under reflux. A strong exothermic reaction occurs and leads to the formation of sodium chloride $\mathrm{NaCl}$ and $\mathrm{Nb}\left(\mathrm{OBu}^{\mathrm{n}}\right)_{5}(0.5 \mathrm{M})$. Sodium chloride was separated by centrifugation resulting in a yellow transparent solution. The final sol was prepared by mixing $\mathrm{Nb}\left(\mathrm{OBu}^{\mathrm{n}}\right)_{5}$ and glacial acid acetic $\left(\mathrm{CH}_{3} \mathrm{COOH}\right)$ with a molar ratio $1: 2$. This sol is stable for several months. The dip-coating method was used to obtain the films. Glass substrates coated with ITO (Asahi Glass) were diped in this sol and withdrawed at a speed of $4 \mathrm{~cm} / \mathrm{min}$, dried at $80^{\circ} \mathrm{C}$ for 15 minutes and densified by heat theatment at $600^{\circ} \mathrm{C}$ during 60 minutes. The procedure was repeated to obtain thicker films.

C) The ion storage coating (IS) or counter electrode consisted of $\mathrm{TiO}_{2}-$ $\mathrm{CeO}_{2}$ layers also prepared by sol-gel processing. The $\mathrm{TiO}_{2}-\mathrm{CeO}_{2}$ precursor sols were prepared using $\mathrm{Ce}\left(\mathrm{NH}_{4}\right)_{2}\left(\mathrm{NO}_{3}\right)_{6}$ salt dissolved in ethanol and to which was added tetraisopropyl orthotitanate with atomic ratio Ce:Ti up to $1: 1$ according to a method already described $[7,11,12]$. The use of isopropanol as solvent (instead of ethanol) leads to a precursor sol stable up to 3 months when kept at $5^{\circ} \mathrm{C}$. The dissolution of the cerium salt results in a clear red solution [11] which becomes colorless after about 30 hours. This phenomenon is due to a slow reduction of Ce $\mathrm{Ce}^{4+}$ according to:

$$
2 \mathrm{Ce}^{4+}+\mathrm{PI}^{i} \mathrm{OH} \rightarrow 2 \mathrm{Ce}^{3+}+\text { acetone }+2 \mathrm{H}^{+}
$$

The presence of the acetone is important for the sol stabilization.

The layers were deposited by dip coating on ITO coated glass at a 20 $\mathrm{cm} / \mathrm{min}$ withdrawal speed resulting in films $50 \mathrm{~nm}$ thick. After drying at room temperature for 15 minutes, the films were partially densified by heat treatment in air up to $550^{\circ} \mathrm{C}$. The whole procedure was repeated up to 5 times to obtain thicker films. 
d) Sol-gel $\mathrm{TiO}_{2}$ protonic electrolyte was prepared according to the method proposed by Judeinstein et al.[16], where however $\mathrm{Ti}\left(\mathrm{OB} \mathrm{u}^{\mathrm{n}}\right)_{4}$ and glycerol $\left(\mathrm{CH}_{2} \mathrm{OHCH}-\mathrm{OHCH}_{2} \mathrm{OH}\right)$ were substituted by $\mathrm{Ti}\left(\mathrm{OPr}^{\mathrm{n}}\right)_{4}$ and ethylene glycol $\left(\mathrm{HOCH}_{2} \mathrm{CH}_{2} \mathrm{OH}\right)$ respectively.

\subsection{Other methods of coatings preparation}

As it is shown later, the electrochromical and optical properties of a complete sol-gel cell are promising but except for the ion storage coating they are still far from reaching those obtained with other methods of preparation. The best results have been obtained in our laboratory using a $\mathrm{WO}_{3}$ electrochromic coating (EC) deposited from the corresponding oxide powder by vacuum evaporation onto ITO/glass substrate. The films were amorphous to X-ray diffraction and their thickness measured with a Talystep was of the order of 200-300 $\mathrm{nm}$. The chemical diffusion coefficient for $\mathrm{Li}^{+}$ions is $\mathrm{D}=2,5.10^{-11} \mathrm{~cm}^{2} / \mathrm{s}$ at $25^{\circ} \mathrm{C}$ [7]. For the cells using $\mathrm{Li}^{+}$ions the ionic conductor layer (IC) was a polymer electrolyte complex prepared by dissolving polyethylene oxide (PEO) powder (M.W. $\left.=9.10^{6}\right)$ and $\operatorname{LiN}\left(\mathrm{SO}_{2} \mathrm{CF}_{3}\right)_{2}$ salt in acetonitrile with an $0: \mathrm{Li}$ atomic ratio of 10:1. The viscous liquid was prepared in a glove box in absence

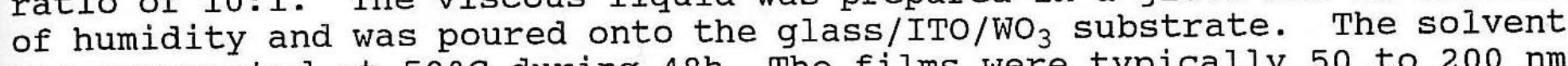
was evaporated at $50^{\circ} \mathrm{C}$ during $48 \mathrm{~h}$. The films were typically 50 to $200 \mathrm{~nm}$ thick. For the cells using $\mathrm{H}^{+}$ions we obtained good results using a cellulose polyacetate protonic gel prepared by diluting $0,5 \mathrm{~g}$ of cellulose monoacetate (Rhodialite-Rhodia-Brazil) in $2 \mathrm{ml}$ of acetone to which $2 \mathrm{ml}$ of an 80 vol\% glacial acetic acid in water was then added. The best ion storage coating (IS) was found to be the sol-gel $\mathrm{TiO}_{2}-\mathrm{CeO}_{2}$ as described above.

\section{CARACTERIZATION OF THE SOL-GEL COATING}

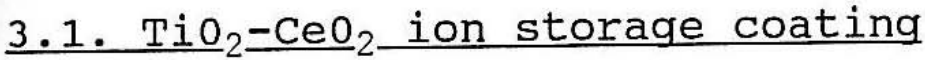

The sol-gel $\mathrm{TiO}_{2}-\mathrm{CeO}_{2}$ coating used as ion storage present a fully reversible ion insertion and extraction process controled by solid state diffusion. The optical transmission of the film is high and remains unaltered during the cyclic process $[7,11,12]$. The total electric charge inserted or extracted during a cycle was measured at the $30^{\text {th }}$ cycle with a Solartron 1286 Electrochemical Interface in a three electrode cell:

$$
\begin{gathered}
\text { Glass/ ITO/ } \mathrm{CeO}_{2}-\mathrm{TiO}_{2} \mid \text { Propylene Carbonate }(\mathrm{PC})-0.1 \mathrm{M} \mathrm{LiClO} \mathrm{O}_{4} \mid \mathrm{Pt} \\
\mathrm{Ag} / \mathrm{Ag}^{+} \mathrm{PC}-0.2 \mathrm{M}\left(\mathrm{Et}_{4} \mathrm{~N}\right) \mathrm{ClO}_{4} \text { (reference) }
\end{gathered}
$$

using a scanning speed of $50 \mathrm{mV} / \mathrm{s}$ and potential limits $-1.8 \mathrm{~V}$ and $0.5 \mathrm{~V}$. The charge density $Q$ inserted or extrated depends of the aging of the sol. It is maximum after $30 \mathrm{~h}$ and corresponds to the state of complete sol optical clearance (figure 2).

Figure 3 shows the influence of the heat treatment temperature on $Q$ for films deposited from a sol aged $30 \mathrm{~h}$ (peak of $\mathrm{fig} .2$ ) and heat treated for $15 \mathrm{~min}$. The highest charge is obtained for treatment performed at 
$\mathrm{T}=450 \pm 20^{\circ} \mathrm{C}$

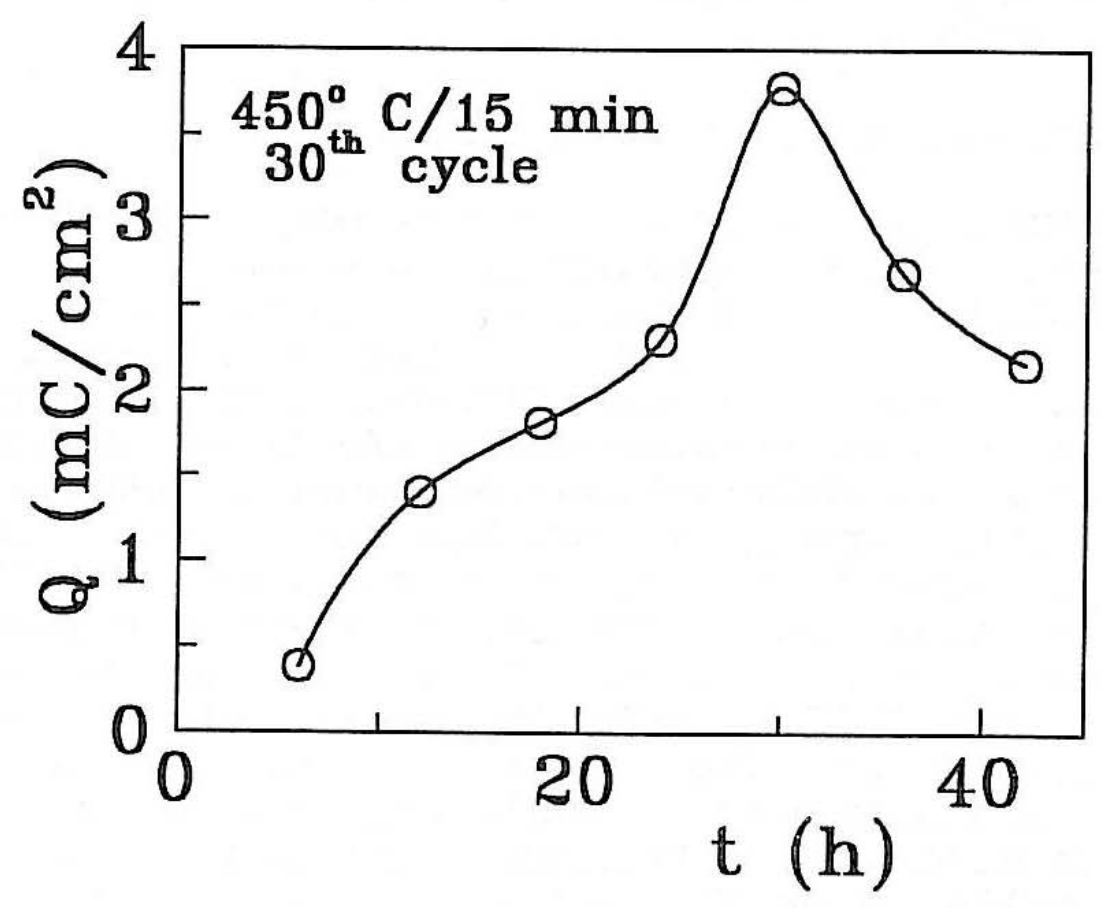

Figure 2. $\mathrm{Li}^{+}$charge density inserted in $\mathrm{TiO}_{2}-\mathrm{CeO}_{2}$ films at the $30^{\text {th }}$ voltammetry cycle as a function of the precursor sol aging time. The films were dried at $80^{\circ} \mathrm{C}$ and densified at $450^{\circ} \mathrm{C}$ for $15 \mathrm{~min}$.

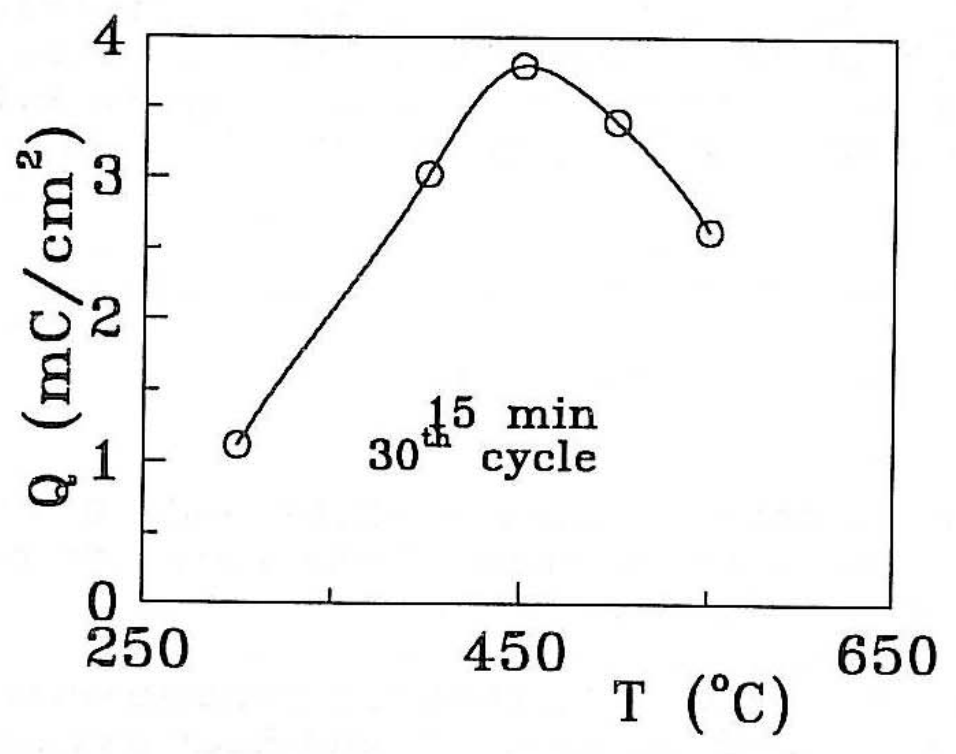

Figure 3. $\mathrm{Li}^{+}$charge density inserted (or extracted) into sol-gel $\mathrm{TiO}_{2}-\mathrm{CeO}_{2}$ films deposited on Baltracon ITO coating during the $30^{\text {th }}$ voltammetry cycle as a function of heat treatment temperature (15 min). The films have been prepared from a RT $30 \mathrm{~h}$ aged sol. 
Figure 4 shows the influence of the heat treatment time realized at $450^{\circ} \mathrm{C}$ on the charge density for films prepared with a $30 \mathrm{~h}$ aged sol. and growth of small $\mathrm{CeO}_{2}$ crystallites [11-12]. The charge becomes constant after $20 \mathrm{~min}$.

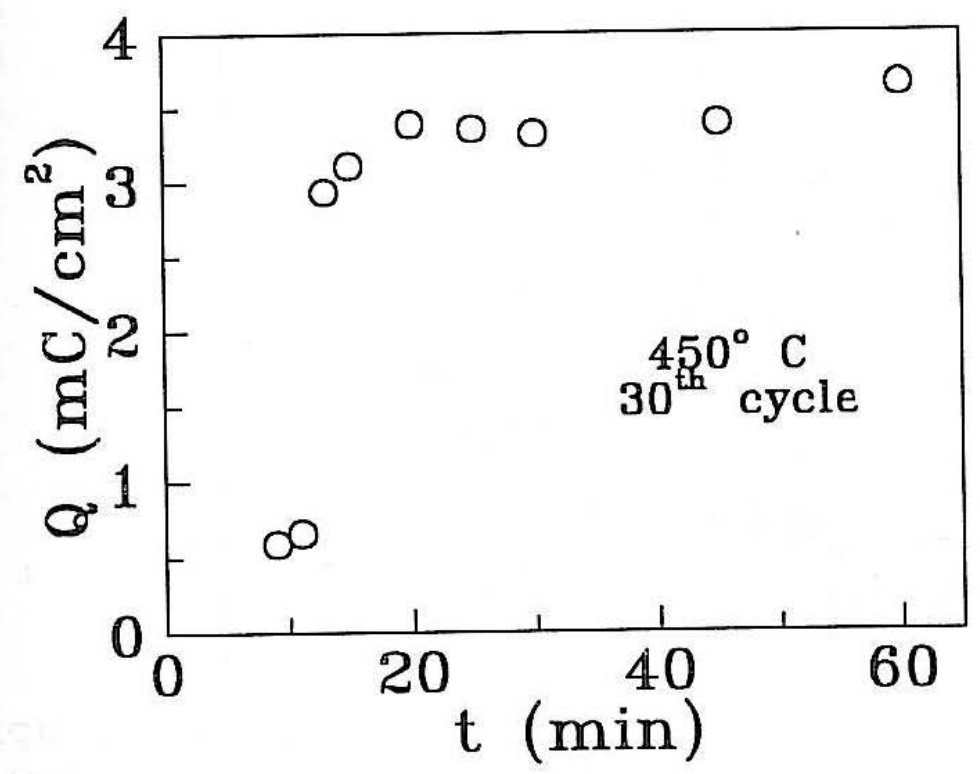

Figure 4. $\mathrm{Li}^{+}$charge density inserted (or extracted) into sol-gel $\mathrm{TiO}_{2}-\mathrm{CeO}_{2}$ films deposited on Baltracon ITO coating during the $30^{\text {th }}$ voltammetry cycle as a function of the heat treatment time at $450^{\circ} \mathrm{C}$. The films have been prepared from a RT $30 \mathrm{~h}$ aged sol.

The influence of the thickness has been tested by preparing layers using up to five successive coatings (fig. 7). The layers have been deposited on four different ITO coatings. All curves passed through a maximum and the charge inserted or extracted dimishes rapidly for thick coatings. The highest charge $\left(\sim 8.5 \mathrm{mc} / \mathrm{cm}^{2}\right)$ was obtained for ITo supplied by Donally and Asahi Glass. The charge density was found independent of the time of heat treatment (fig. 4) and we conclude that the increase of $Q$ observed when the thickness of the layers increases is due to an increase of the number of sites for Lit insertion. The drop observed for larger thickness is not understood and may come from changes in the electrical characteristics of the ITO layers submitted to heat treatment at $450^{\circ} \mathrm{C}$, to a decrease of the Lit diffusion coefficient when its concentration reaches a certain value, or most probably to an increase of the electrical resistance of the ion storage layer as its thickness increases. This will cause a drop of the potential at the electolyte counter electrode interface and consequently will reduce the amount of charge inserted into the electrochromic layer. This effect may in principle be compensated by increasing the applied potential. 


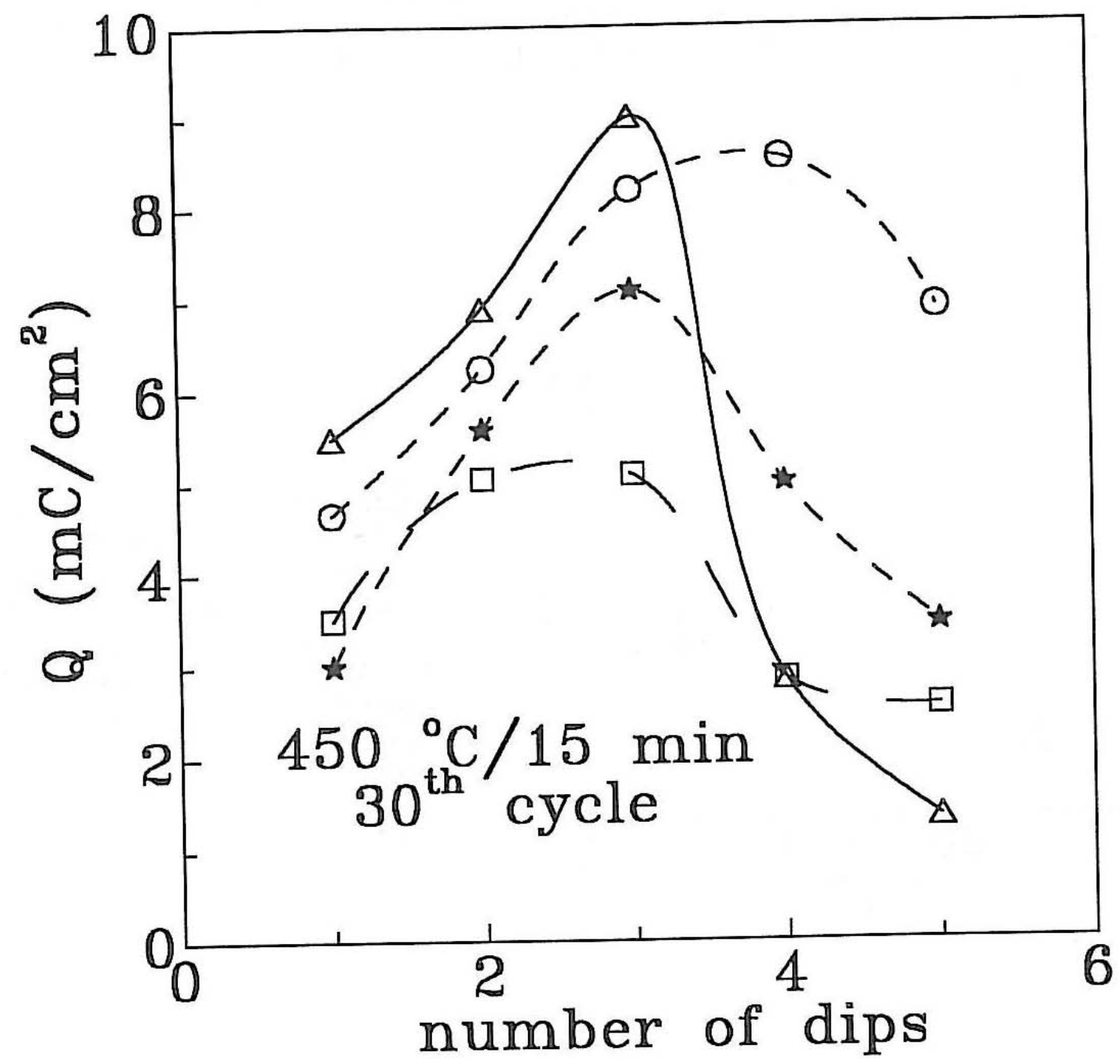

Figure 5. $\mathrm{Li}^{+}$charge density inserted (or extracted) into sol-gel $\mathrm{TiO}_{2}-\mathrm{CeO}_{2}$ as a function of the number of dips. The films have been deposited on ITO supplied by (口)Balzers, ( $\left(\frac{1}{)}\right.$ Asahi Glass, (O)Asahi Glass previously heat treated at $450^{\circ} \mathrm{C}$ during $15 \mathrm{~min}$ in air and $(\Delta)$ Donally.

\section{$\underline{3.2}_{2} \mathrm{Nb}_{2} \underline{O}_{5}$ electrochromic coating}

The optical transmissions of a $\mathrm{Nb}_{2} \mathrm{O}_{5}$ thin coating are shown in figure 6 . These spectra were measured after applying potential from $-2.8 \mathrm{~V}$ ( $\mathrm{Li}^{+}$insertion) and $-0.5 \mathrm{~V}$ ( $\mathrm{Li}^{+}$extraction). The transmission in the visible range is superior to $70 \%$ in the bleached state, and drops to less than $20 \%$ in the colored state. The good electrochemical reversectrochromic optical density indica
layer in EC devices. 


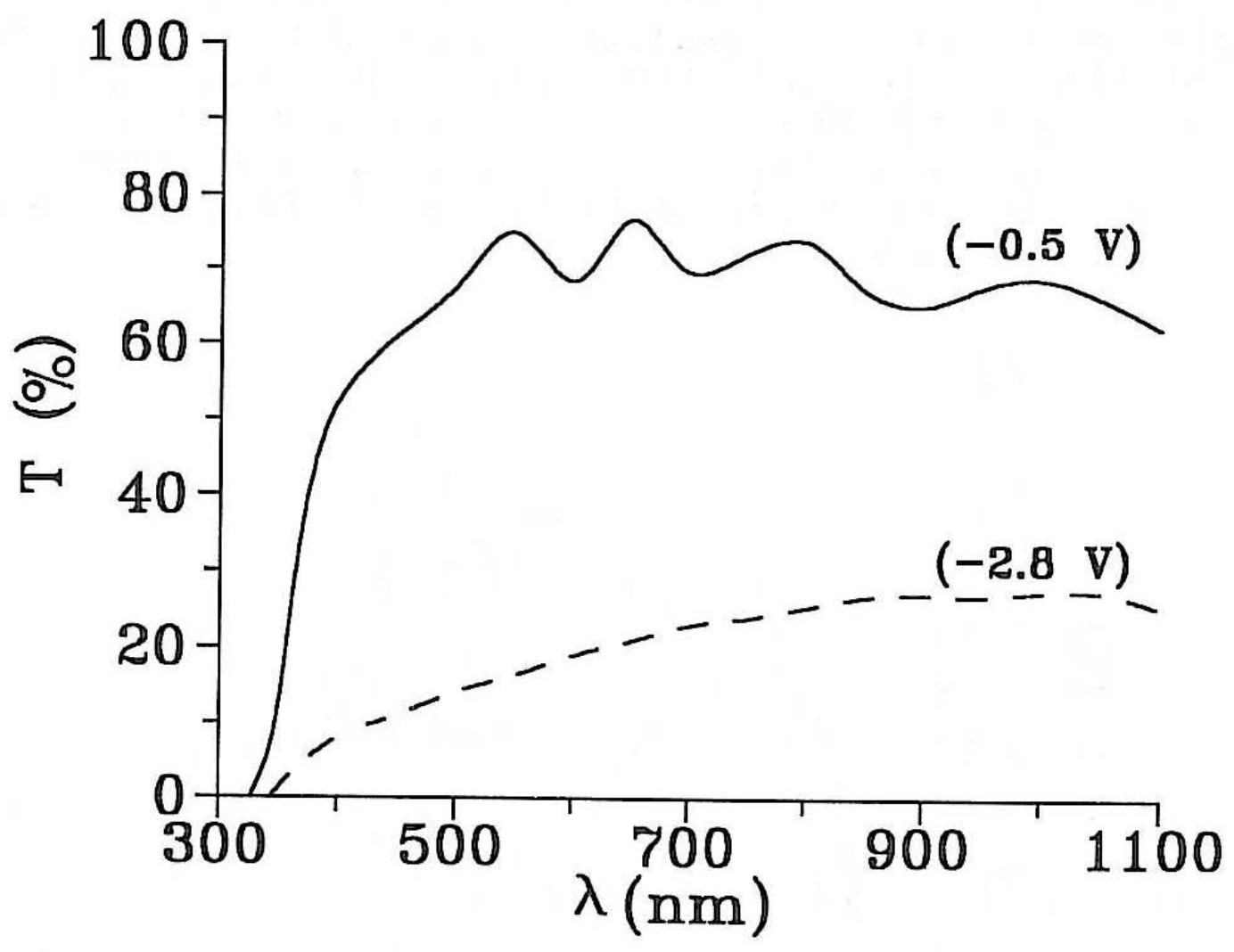

Figure 6. Optical transmission of sol-gel $\mathrm{Nb}_{2} \mathrm{O}_{5}$ coating ( 3 dips) in bleached $(\longrightarrow$ and colored $(---)$ states.

\section{CHARACTERIZATION OF TRANSMISSIVE DEVICES.}

We present the optical transmission of two all solid state eletrochromic windows

Glass/ITO/ $\mathrm{WO}_{3} / \mathrm{H}^{+}$electrolyte (sol-gel) $/ \mathrm{TiO}_{2}-\mathrm{CeO}_{2}$ (sol-gel)/ITO/Glass

All the coatings of the first cell were realized by the sol-gel process as described above (2.1). The second cell was mounted using a better WO $_{3}$ spectra of both in our laboratory (see 2.2). The optical transmission 7. Both systh windows in the visible-near IR range is shown in figure bleaching systems can be cycled and present stages of coloration and is due to the sol-gel window has still a low transmission variation. This have not been fact that the parameters of the eletrochromic coating WO $_{3}$ The necond ceen optimized (thickness, temperature of densification, etc). which is redull has a transmission of about $75 \%$ in the bleached state has a fast reduced to about $25 \%$ at $600 \mathrm{~nm}$ in the colored state. This window hast optical response. However both cells have a relatively short 
life time because of the corrosion of the $\mathrm{WO}_{3}$ and/or ITO layers by the acidic electrolyte. Nevertheless we have shown that a complete electrochromic cell can be realized using the sol-gel process. The preparation of the sol-gel $\mathrm{CeO}_{2}-\mathrm{TiO}_{2}$ coating has been optimized and the results presented indicat that it can be used with advantages as $\mathrm{H}+$ and $\mathrm{Li}+$ storage layer in such devices. Considerable work should be done now to optimize the electrochromic sol-gel layer $\left(\mathrm{WO}_{3}\right.$ or $\left.\mathrm{Nb}_{2} \mathrm{O}_{5}\right)$ and the protonic $\mathrm{TiO}_{2}$ electrolyte.

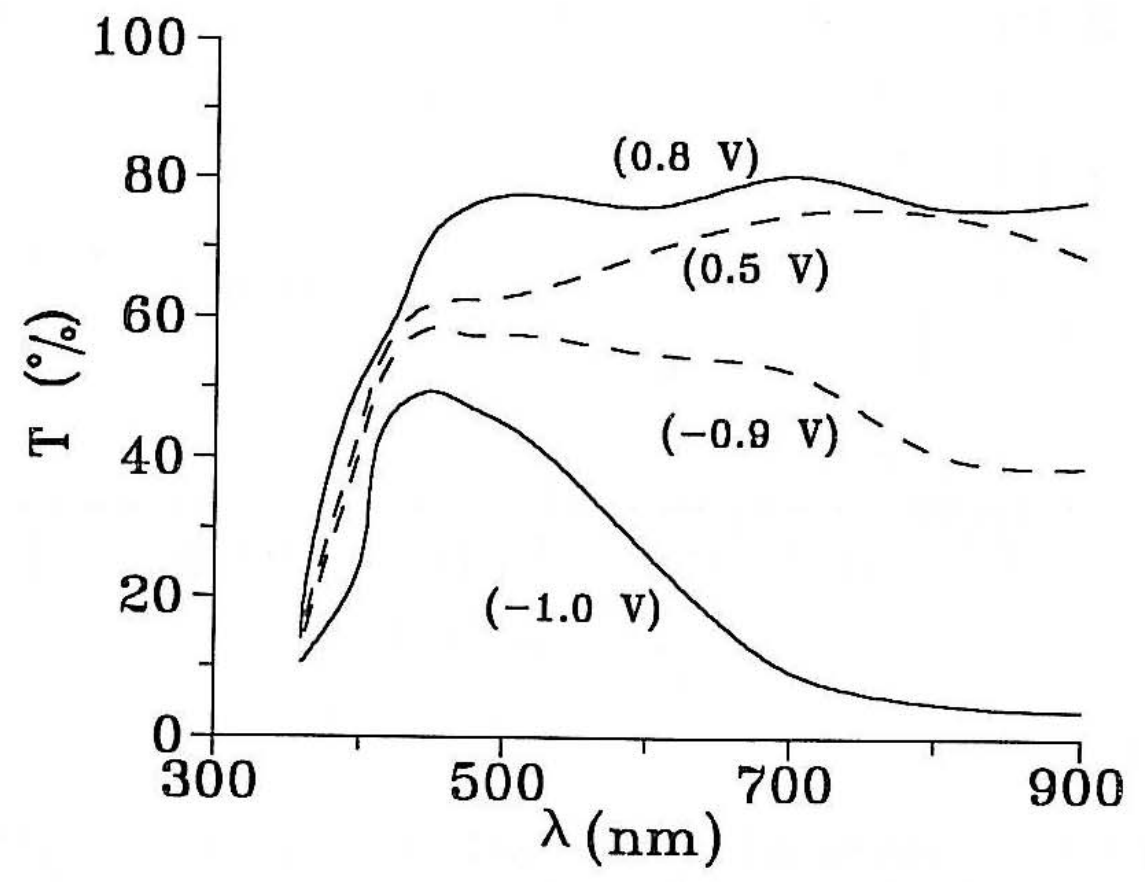

Figure 7. Optical transmission of two electrochromic windows having the configuration: glass/ITO/ $\mathrm{H}_{\mathrm{x}} \mathrm{WO}_{3} / \mathrm{TiO}_{2}-\mathrm{sg} / \mathrm{CeO}_{2}-\mathrm{TiO}_{2}-\mathrm{sg} / \mathrm{ITO} / \mathrm{glass}$ where $(\longrightarrow$ is a vacuum evaporated $\mathrm{WO}_{3}$ and (---) is a sol-gel (sg) $\mathrm{WO}_{3}$.

\section{CONCLUSION}

An all solid state electrochomic window has been realized using solgel coatings such as $\mathrm{WO}_{3}$ (electrochomic layer), $\mathrm{TiO}_{2}$ (proton electrolyte) and $\mathrm{CeO}_{2}-\mathrm{TiO}_{2}$ (ion storage layer). Its optical transmission in the colored and bleached states has been measured and compared to similar window whose $\mathrm{WO}_{3}$ coating has been prepared by evaporation. Although its performance are still far from the best device built in our laboratory, we have shown that the realization of an all sol-gel electrochomic device is feasible. However considerable work should be performed to optimize its performance. This has already be done for the sol-gel $\mathrm{CeO}_{2}-\mathrm{TiO}_{2}$ ion storage layer for which the electrochemical properties have been determined as a function of different preparation parameters such as aging of the sol, time and temperature of the densification process, thickness of the coating and type of ITO coating. The highest charge density was of the order of 8.5 
$\mathrm{mC} / \mathrm{Cm}^{2}$

We believe that the good electrochemical properties of the ion storage layer come in part from the possibility, through the sol-gel process, to tailor an optimum porous texture of the layers via controlled heat treatment.

\section{ACKNOWLEDGMENTS}

This research has been financially supported by FINEP, FAPESP, CNPq and the Program RHAE - New Materials (Brazil).

\section{REFERENCES}

1. C.M. Lampert and C.G. Granqvist, Large - Area Chromogenics: Materials and Devices for Transmittance Control, SPIE vol IS4, Bellingham, 1990. 2. B.W. Faughnan, R.S. Crandall and P.M. Heyman, RCA Rev. 36, 177, 1975. 3. T.E. Haas and R.B. Goldner, reference 1, 170 .

4. M.B. Armand, "Current State of PEO-Based Electrolyte", Polymer Electrolyte Review 1, ed. J.R. MacCallum and C.A. Vincent, 1, Elsevier App.Science, 1987.

5. J. Nagai, M. Mizuhashi and T. Kamimori, reference 1, 378 .

6. R.D. Rauh and S.F. Logan, Solid State Ionics, 28-30, 1707, 1988.

7. P. Baudry, M.A. Aegerter, D. Deroo and B. Valla, J. Electrochem. Soc. $138,460,1991$.

8. R.B.Goldber, T.E.Haas, G.Seward, K.K.Wong, P.Norton, G.Foley, G.Berera, G. Wei, S. Schulz and R. Chapman, Solid State Ionics, 28-30, 1715, 1988. 9. S.F. Logan and R.D. Rank, reference 1, 482 .

10. D. Deroo, P. Baudry and H. Arribart, French Patent No 8808809.

11. J.C.I. Tonazzi, B. Valla, M.A. Macedo, P. Baudry and M.A. Aegerter, Sol-gel Optics, SPIE, vol 1328, 375, 1990.

12. M.A. Aegerter, P. Baudry, D. Deroo, M. Armand, Patent Pending $N^{\circ} W_{0}$ 91/02282 (PCT/BR90/00006).

13. M.A.Macêdo, L.H.Dall'Antonia and M.A.Aegerter, Sol-Gel Cochings for Electrochromic Devices, to be published in Smart Materials Fabrication, Mat Res. Soc. Proceedings, Spring Meeting, San Francisco 1992.

14. C.J.Brinker and G.W.Scherer, Sol-Gel Science, Academic Press, Inc (1990).

15. P.Judeinstein (Ph.D Thesis, Université de Paris, 1989).

16. P.Judeinstein, J.Livage, A.Zarudiansky and R.Rose, An "all gel" electrochromic device, Solid state Ionic 28-30, 1722-1725, 1988 .

17. R.C.Mehrotra, "Synthesis and Reactions of Metal Alkoxides", J. NonCryst. Solids 100(1988)1-15. 